Article

\title{
At the Interface of National and Transnational: The Development of Finnish Policies against Domestic Violence in Terms of Gender Equality
}

\author{
Tuija Virkki
}

Department of Social Sciences and Philosophy, University of Jyväskylä, Jyväskylän yliopisto 40014, Finland; tuija.virkki@jyu.fi; Tel.: +358-408-053-388

Academic Editor: Nancy A. Naples

Received: 28 December 2016; Accepted: 9 March 2017; Published: 15 March 2017

\begin{abstract}
Although gender inequalities are the main social mechanisms behind the (re)production of domestic violence, policy responses to domestic violence as a gender-related problem vary at both the national and transnational levels. This article examines the interaction between national and transnational policies against domestic violence, focusing on how domestic violence is constructed as a gender-related problem in Finland, a Nordic welfare state that is often cited as a role model in gender equality. Using the conception of policies as historically changing and culturally specific discourses, this article offers an overview of the ways in which the perspective on domestic violence of the transnational feminist movement has been engaged and transformed in the Finnish context over the five last decades. It is shown that transnational pressure has played a critical role in pushing Finland towards a stronger recognition of domestic violence as a gender issue. However, this transformation has taken place rather within the framework of more neutral "women-friendly" welfare policies than within a feminist framework. The article concludes that the Finnish way of translating transnational norms to the national level is characterized by a tendency to modify the transformative meanings underpinning the transnational feminist discourses to a more gender-neutral form.
\end{abstract}

Keywords: domestic violence; violence against women; policy responses; gender equality; feminist movement; transnational perspective; interaction between national and transnational; social policy; welfare states; Finland

\section{Introduction}

This article takes Finland as an illustrative case study of a Nordic-style "women-friendly" welfare state with obvious shortcomings in responding to violence against women. Finland is often represented as a world leading pioneer in gender equality issues. For example, the World Economic Forum's Global Gender Gap-Report 2014 [1] ranks Finland second in women's access to education, healthcare, politics and employment. However, a European Union (EU) wide survey [2] shows that Finland is the EU's second most violent country for women. Moreover, previous studies [3,4] show that Finland has been peculiarly reluctant to address this problem and the question of gender inequalities linked to it even in the face of increased outside pressure to do so.

My article addresses a specific form of violence against women, domestic violence (DV) which dominates public discussions in Finland, by investigating the development of Finnish policies against DV in terms of gender equality. Although gender inequalities have been shown to be the main social mechanisms behind the (re)production of DV, the understanding of the relationship between DV and gender equality may vary from approaches that explicitly link DV to gender equality to approaches that contest the premises of gender equality thinking in relation to DV [5]. Utilizing Carol Bacchi's [6] conception of DV policies as discourses, I analyze the construction of DV as a gender equality related 
policy problem in Finland. A guiding premise in this analytical approach is that the specific objects of policies are created in and through discourse. It is, therefore, crucial to consider policies not, simply, as responses to problems that exist "out there" in society, waiting to be solved through policy interventions, but rather as competing interpretations of given problem areas.

I explore the historically changing and culturally specific constructions of DV as a problem of gender equality in Finland, thus locating the analysis of these constructions at the intersection of time and space. Most importantly, I examine the interaction between national and transnational policies in the ways in which DV has been constructed as a problem of gender equality in Finland. Research on the situational contexts and historically changing constructions of DV calls for an analysis of the interaction between DV policies on the national and transnational levels. In today's globalized and pluralistic world, national policies are influenced by various transnational actors and DV policies in many ways, and thus national policies also develop in relationship to transnational policies. While the notion of transnational can be understood in many ways (e.g., [7]), it is used here to refer to activities initiated and sustained by intergovernmental and international non-governmental organizations (NGOs), both institutional and non-institutional, and by social movements, advocacy groups and networks across nations and national borders.

Many researchers have noted the importance of cooperation between international organizations (e.g., United Nations, World Health Organization, European Council, and EU), and the transnational feminist movement and women's networks for the development of national policy responses to DV, thereby linking the global to the local. As Marianne Hester [8] remarks, it is difficult to discuss DV in different locations across the globe without considering the impact of globalization and transnational DV policy debates, as these are likely to impact DV policy development and action in specific countries. Transnationally, since the 1970s, DV has shifted from being a private issue, to being recognized as a public issue and organized against at a global level. DV became part of global social policy when, following pressure from feminists in the 1980s, the issue began to be acknowledged by the United Nations (UN) and was eventually established as a human rights violation and welfare issue in diverse settings $[8,9]$.

Of particular importance in placing the issue of DV on the UN agenda was pressure from the transnationally organized feminist movement $[8,10]$. In fact, transnational human rights organizations, such as Amnesty International and Human Rights Watch, had not recognized violence against women as a violation of human rights until they were pressed to do so by feminist activists. National policymaking increasingly became affected by transnational institutional measures and norms through the influence of a series of major world conferences, global treaties, and regional agreements requiring state-based interventions. What is interesting in the European context is that the EU framed DV as a component of gender inequality after the mid-1990s when it began to expand its jurisdiction beyond economic matters to include social issues, especially human rights, and to urge member states to take action against DV [11]. However, equally essential for my exploration of the interconnections between the national and transnational is to shift the focus back to the importance of national context in constructing and implementing transnational policy frameworks.

This article is premised on the idea of transnational motion as an effect of interaction between transnational and national, as this enables a reciprocal understanding of how transnational and national interrelate and constitute each other [12]. According to this idea, discourses and policies move from one country, movement or institution to another, a process during which they become translated in different ways $[9,13]$. To become meaningful to people in specific contexts and locations, transnational influences are always mediated through culturally specific assumptions and knowledge as each locality of adoption brings new meanings and practice to the "original" formula. The localization of transnational policies can be seen as a continuous process of rearticulation and recontextualization in which, somewhat paradoxically, forms of local appropriation and resistance are in process at the same moment as cultural homogenization and absorption [14]. 
A recent study of the translation of transnational norms on DV to national levels [5] indicates that gender equality is a dynamic, contested concept that takes on different meanings in different contexts and among different stakeholders. Moreover, transnational norms are themselves ambivalent, heterogeneous, evolutionary, and often sending incompatible normative signals [12]. The translation of transnational norms on DV to national levels may stretch the gender equality ideas underpinning those norms to more easily gain their endorsement by mainstream policy actors, and thus may result in policies constructed in degendered terms. In this way, local approaches to the issue of gender inequality influence how transnational DV discourses become locally appropriated, stretched, shrunk or opposed [15]. Such interaction between national/local and transnational/translocal is the focus in this article.

Drawing on previous research on national DV policies in Finland as well as research on the development of DV policies at the transnational level and in other countries, I offer an overview of the ways in which the transnational gender equality perspective on DV has been engaged, transmitted, and transformed in the specific context of Finland over the past five decades (1970s-2010s). Previous research on Finnish DV policies consists of peer-reviewed journal articles [3,16-19] and books chapters [20,21], as well as PhD [22] and Master's theses [23,24], based on analyses of policy documents, various materials related to legal changes, expert interviews, parliamentary debates and participant observation. Most of this scholarly work compares the case of Finland to that of Britain [21,23], Scotland [3] and Russia [19], thereby providing a cross-cultural view of the development of DV policies in Finland. However, compared to the previous research, this article addresses the development of Finnish DV policies more comprehensively by exploring a longer time period and viewing DV policy development from the wider perspective of interaction between the national and transnational levels.

\section{Key Developments in the Finnish Policies against DV}

First, I shall present some background information about Finland. Finland is culturally, politically and economically a Western European country, parliamentary republic with a population of approximately 5.5 million. Geographically, it is located in Northern Europe and neighbored by Sweden, Norway, Russia and Estonia. Historically, Finland was under Swedish rule until 1809, after which it was an autonomous Grand Duchy in the Russian Empire until 1917. The period of Russian rule generated a nationalist Finnish movement for independence, which encouraged Finns to build coalitions towards this common goal [25]. The attempt to unify all social forces went hand in hand with a democratization project, electoral system changing from a four-estate system to universal suffrage already in 1906. During the Russian Revolution in 1917, Finland declared its independence.

In World War II, Finnish forces fought against the Soviet Union. Finland became a member of the UN and the Nordic Council in 1955 and established an official policy of neutrality during the Cold War (i.e., the political and military tension between the dominant powers in the Western and Eastern Bloc). To maintain international balance, Finland required broad national unity, which in turn reinforced the existing consensus-orientation in its political culture. Finland's neutrality prevented it from joining the European Union and the European Human Rights system until the end of Cold War. Finland joined the Council of Europe in 1989 and the EU in 1995.

As a relative late comer to industrialization, Finland remained a largely agrarian country until the 1950s. Thereafter, it rapidly developed into an advanced economy, building itself into a Nordic-style welfare state in the 1970s and 1980s, and achieving recognition as a top performer in the fields of economic competitiveness, education, civil liberties, and quality of life [26]. Following its centuries long period of Swedish rule, Finland has retained the major social and legal traditions of Sweden, specifically with regard to family law [17]. Finnish social welfare policies have drawn on the cultural traditions of the Nordic countries and, as a result, Finland has been a pioneer in gender equality in politics, education, employment and welfare services. However, Finland differs markedly from the other Nordic countries in not recognizing DV as a pivotal issue for gender equality. I will now turn to 
a historical overview of the development of Finnish DV policies beginning from the 1970s and 1980s when the agenda was initially set, and ending with the present day.

\subsection{The Initial Agenda Setting in the 1970s and 1980 s}

What is referred to as the "new" or "second wave" feminist movement emerged in the United States (US) in the 1960s, and subsequently spread to Western Europe [20]. The movement began to address DV as a major violation of women's human rights in the 1970s. While the feminist movement against DV comprised multiple configurations of microcohorts, it was united in its goal of addressing systematic power relations and inequalities between men and women as the key causes of DV [27]. It was often radical or social feminists who took up the issue, and owing to their skepticism about state-level solutions, focused their efforts on local grassroots service provisions. The burgeoning feminist shelter movement in the US and the United Kingdom (UK) was the main example of grassroots mobilization, and it was also the main route through which the feminist discourse on DV was imported to other countries. Besides providing help and support for female victims of DV, feminist shelters educated the general public about the genderedness of DV and worked to put the issue on the political agenda [28].

Prior to the end of 1980s, transnational and intergovernmental organizations played only a minimal role in promoting policies to combat DV [11]. During this time period, reform of the gendered constructions of DV required strong local feminist advocacy from outside and/or inside governments. The role of the feminist movement was on softening up the political environment, changing the national mood, and putting the issue of DV on the agenda [10]. Of interest in the case of Finland is that the neighboring Swedish feminist advocates were able to push for change via a strong feminist movement and a fairly responsive government. Much like their Anglo-American counterparts, the Swedish feminist movement was in the vanguard of the violence against women campaign in the 1980s [29]. Swedish women began to form political organizations aimed at eliminating DV; they organized women's shelters nation-wide and gained public support through extensive media campaigns. Eventually, the Swedish state responded to these local pressures with changes in law enforcement and juridical procedures.

As in Sweden, a long tradition exists in Norway, Denmark and Iceland of women's shelters organized by the feminist movement. Although previous research shows that DV discourses have typically diffused regionally into neighboring countries [30], the situation in the Finland of the 1970s and 1980s differed markedly from that of the other Nordic countries. Perhaps due to the relatively late process of modernization in Finland, feminist activity on the issue of DV did not arrive in the country until the end of the1970s and, even then, did not succeed in gaining a significant foothold. Initially, a struggle took place over the key meanings of DV in seeking to underpin the establishment of a shelter network. The main women's NGO, the League of Finnish Feminists, constructed the problem of DV in gendered terms, whereas the much older and more established child welfare organization, the Federation of Mother and Child Homes and Shelters, defended the more traditional discourse of "family violence" [22,24]. In contrast to the feminist discourses that conceive DV as a consequence of gender inequality, the family violence discourse addresses the problem of DV in gender-neutral terms, ascribing it to communication problems or to alcohol- or mental health-related problems within the family [3,17].

The outcome of this struggle over the definition of DV during the late 1970s was that the gender-neutral construction of DV as a family-centered problem remained dominant. Consequently, shelters were established for all victims suffering from "family violence", and from the start their explicit aim was to work with the whole family, and not only with women and their dependents [31]. Unlike the shelters founded in the other Nordic countries which often grew out of feminist activism and focused on feminist approaches, the Finnish shelter network developed out of the pre-existing child welfare institutions and put the emphasis on child protection and a family-centered approach, with the main goal of offering safe homes for children [21]. As DV was seen primarily as a consequence 
of family dynamics, relationship disputes and other problems within the family, every effort was made to bring about reconciliation between the conflicting parties [20]. On this view, DV was not caused by any factors at the structural level of society and, therefore, solutions to the problem were to be found on the individual level [21]. DV was seen as a social problem only in the limited sense of constituting a small component of bigger social problems such as alcoholism, mental health problems or unemployment, which required therapeutic interventions and/or practical social policy solutions.

In this way, the initial Finnish DV agenda, policies and service system were set by non-feminist actors, and the dominant discourses constructed DV as an outcome of unhealthy family dynamics or as an alcohol- or mental health-related problem, rather than as an issue linked to gender inequality and gendered power relations [17]. Compared to other Western countries, the absence of feminist discourse on DV in 1970s and 1980s Finland has been described as "striking" ([16], p. 89). Previous research [32] has offered various reasons for this, most of which refer to the Finnish paradox of official gender equality combined with a persistent rejection of feminist and gender-specific discourses. This paradox has been shown to arise out of various historical, political and sociocultural circumstances spesific to Finland.

The Finnish official equality policy, then, has been based on the ideal of gender-neutral similarity rather than difference between women and men [32]. This understanding of the equality of men and women stems from the traditions of Finland's collectivist agrarian society and the building of an equalitarian welfare state, both projects in which women were needed to work alongside men as active agents [33]. Yet the building of the Finnish welfare state focused on promoting the good of all in society rather than emphasizing issues that were perceived as being of importance "only" for women. The official gender equality discourse in Finland was primarily concerned with promoting the full-time participation of women in the labor market and finding ways of combining work and care responsibilities [25]. The project was "pro-family" rather than "pro-women" and, as such, it did not question gender inequalities. In fact, it has been argued that Finnish equality policies have been progressive in terms of the rights of women as employees, mothers and carers, but conservative on issues relating to women's bodily rights and bodily integrity [17].

In contrast with "maternalist" issues such as maternity leave or child-care, which women can advocate without straying too far from conventional ideas about women's role in society, addressing DV in gendered terms requires challenging male privilege and the social norms of male domination in a way that is not compatible with the consensus-oriented approach and the ideals of overall neutrality predominant in the Finnish political culture. The avoidance of any confrontations between men and women may be the main reason why the radical feminist movement and issues typically raised by radical feminists such as their critique of men's violence against women were sidelined in Finland in the 1970s and the 1980s. It might also be one reason why the action taken in Finland to combat the problem of DV was one of gender-neutral and non-confrontational reform by non-feminist actors. In this respect, Finland differed greatly from, for example, Sweden, where the feminist social movement was the "primus motor" for action towards DV. In conclusion, it seems that the gender-neutral construction of DV was so deep-rooted and pervasive in Finland in the $1970 \mathrm{~s}$ and 1980s that far stronger outside impacts or extreme pressures were needed to induce any shift towards a feminist interpretation of DV.

\subsection{The Breakthrough in the 1990 s}

The increasing transnational prominence of the issue of DV and the emerging transnational norms on DV in gendered terms allowed for the creation of spaces where the adoption of new discourses on DV became possible, thus contributing to Finnish DV policy development throughout the 1990s [21]. The transformation at the transnational level was due to the fact that feminist movement had become increasingly influential in shaping DV policies not only through domestically focused activism, but also through transnational advocacy [10]. Some feminists organizing across borders had begun, independently of national government processes, to push for the inclusion of DV in international agreements on human rights in the mid-1970s and, more strongly, in the late 1980s. As a result of 
feminist activism, several transnational declarations, treaties, and agreements on DV as a gendered issue proliferated during the late 1980s and the 1990s.

In 1979, the General Assembly of the UN adopted the Convention on the Elimination of All Forms of Discrimination Against Women (CEDAW), which was a groundbreaking contribution in gendering international human rights laws [25]. In addition, the CEDAW recommendation on violence against women was the first international articulation in terms of human rights. However, the first major declaration recognizing violence against women as a violation of women's human rights was the UN's Declaration on the Elimination of Violence Against Women, a product of the 1993 World Conference on Human Rights held in Vienna [10]. Thereafter, the transnational movement gathered momentum, resulting in stronger language and clearer recognition of the issue in the 1995 Beijing Declaration, which named violence against women a critical area of concern. Both declarations signaled the progress in transnational norms that in turn created pressures for DV policy development in many locations, including Finland [24].

After Finland had acceded to the EU and the Council of Europe in 1995, the most important influence on Finland came from the EU [21]. The main EU initiatives aimed at combatting violence against women occurred primarily after the mid-1990s, since it was not until the late 1990s that the EU began to expand its jurisdiction beyond economic matters to include social issues and human rights [11]. European feminist activists from within and outside EU institutions took advantage of the political opportunities provided by CEDAW and the Vienna and Beijing Declarations to lobby the EU to take a more active stance on DV. Their efforts helped place the issue on the agenda not only of EU institutions but also of many member states. The shift toward EU action in supporting of policy reform began in 1997 with the EU-wide Campaign for Zero Tolerance of Violence against Women, premised on the above-mentioned transnational declarations and treaties.

As a regional actor, the EU spread transnational norms by emphasizing the important ways in which these norms apply to the specific states in question and to their European identity $[11,34]$. The term "Europeanization" captures the way in which the European dimension becomes an embedded feature framing politics within the EU member states. The EU has been influential in negotiating and synthesizing transnational discourses of violence against women and providing new discourses about DV [21]. In addition, the EU has played an important role in the creation and legitimation of new policy actors and institutions, such as the European Policy Action Centre on Violence against Women and the Women Against Violence in Europe (WAVE), that have articulated feminist discourses on DV and ensured their presence at the EU level. While these developments took place beyond the state borders, they had the potential to influence member states' DV policies.

However, in the 1990s, EU policies on DV developed within the boundaries of "soft law" (guidelines, recommendations, and action plans) and not with legally binding directives [11]. Therefore, "Europeanization" provided a process of convergence towards a shared policy framework which did not, however, require uniformity, or imply an erosion of, or overriding the member states' internal processes. In this way, the influence coming from the EU was subject to the same interactive dynamics between the local and translocal as the influences coming from the UN and other transnational actors. It is typical of these dynamics that complex and widely differing domestic processes ensue after the initial national recognition of transnational norms [12]. Each national context represents a mix of various values systems, all of which have the potential to overlap with and differ from transnational norms, thus translating them differently into the national levels.

The CEDAW process in early 1990s Finland provides an illustrative instance of the way in which the adoption of transnational norms may go hand in hand with locally differing interpretations of those norms. As part of its function of monitoring the CEDAW-process, the CEDAW-committee voiced its criticism of shortcomings in Finnish DV policies in 1989, and the Finnish women's organizations subsequently deployed this criticism to prod the state towards policy development [22,24]. What is characteristic of the situation in Finland, the role of non-governmental feminist mobilization against DV was quite modest, and the most prominent proponents of the equality perspective were either 
state-oriented or part of state institutions [24,25]. In 1990, the Finnish Council for Gender Equality, a parliamentary council with an advisory function to the government, set up a special committee to address this issue. By employing the concept of "violence against women" as opposed to "family violence", the committee sought to formulate a feminist discourse. In this way, the CEDAW provided a discursive framework and an incentive to put DV on Finland's national agenda and to strengthen differing understandings of gender equality, while for their part, the domestic activists magnified the effect of CEDAW by intensifying the pressure on the national government and, hence, contributing to the incorporation of feminist discourses into the national framework [25].

The committee, however, consisted of experts and politicians who drew upon a more moderate discourse, one that can be described as a "women-friendly welfare discourse" ([21], p. 104) This discourse is related to the building of the Finnish welfare state and has its origins in the earlier gender-neutral definitions of DV as a component of other social problems, such as alcoholism and poverty, and thus sees practical social policy solutions as the most appropriate means to tackle the problem of DV. Although the committee sought to underline the issues of gender equality and women's rights, it seems that the women-friendly welfare state discourse did not succeed in posing any real challenge to the formerly dominant family violence discourse. In fact, what unites these two discourses is their emphasis on understanding the problems of the male perpetrators (e.g., alcoholism and social exclusion) and seeking to alleviate them by means of social policy solutions. While the focus on male perpetrators can represent either gender-specific or gender-neutral constructions of DV, in this case, the gender-neutral constructions were favored. Whereas the committee demanded, for example, the prosecutions of the perpetrators of DV, it ended up recommending that the main responsibility for national-level coordination of DV policies should lie with the Social Affairs and Health Ministry.

According to previous research [21], the prominence of the women-friendly welfare discourse is characteristic of the Finnish way of translating transnational norms into the national level throughout the 1990s. Typical of this discourse is that it places trust in the welfare state and in social policy solutions as the main means of promoting a "women-friendly" society also in the context of DV. It represents state-feminism in that it seeks to promote gender equality by incorporating many of the feminist movement's demands into government policies, albeit in the specific context of a welfare state. In the 1990s, 33\% to 38.5\% of Finnish parliamentarians were women, and the national parliament has been one of the most crucial public spaces to discuss gender issues, which, in part, explains the state-orientation of Finnish women's organizations [25]. While many feminist movements elsewhere have viewed with caution too close engagement with the state in their belief that the patriarchal state condones all form of male violence against women, in Finland the more consensus-oriented nature of the development of a welfare state has meant that feminists have been more willing to work "inside" the state apparatus [23]. The drawback for Finnish feminists of using the women-friendly welfare state discourse in DV debates is that the transnational norms and gender equality agenda have been watered down as the problem of DV has been constructed mainly as a social policy problem that needs welfare state orientated solutions [21].

Nevertheless, the women-friendly welfare state discourse has played an important role in the breakthrough in the general development of Finnish DV policies. As a joint effect of transnational, regional and national influences, Finnish DV policies expanded after the mid-1990s. In 1997, the Finnish government prepared its Plan of Action for the Promotion of Gender Equality, and, in 1997, the Social Affairs and Health Ministry was took up its role as the lead governmental department on the issue by launching the first national Program for the Prevention of Prostitution and Violence against Women (1997-2002). The overall aim of the work undertaken in the program was to raise awareness of violence against women and of its extent and impact on individuals and society, including the promotion of community initiatives at various levels [3]. Numerous services for the various parties involved in DV were launched, including a help-line for the victims of crime and perpetrators' programmes for violent men. 
Although the focus in the Finnish policy development in the 1990s was not on legal reforms, some evolution can be traced in the legislation on DV and the active role of the state in enhancing the legal protections of the victims of DV [16,22]. Prior to the 1990s, DV could only be dealt with under the 1889 criminal law, which distinguished between violence in public and private spheres, and marital rape was not recognized as a criminal act. In 1995, major assaults in a private place became a mandatory public prosecutorial case. The marital exemption in instances of rape was abolished in 1995, Finland being one of the last European countries to do this. An act on the restraining order was passed in 1998, and was the first concrete legislative measure to address DV [18]. Although the law itself is gender-neutral, it was passed out of awareness and concern for violence against women and out of need for special action.

Despite all this progress, abundant evidence exists on the persistent reluctance to the adoption of the transnational norms by applying explicitly feminist discourses on DV in the 1990s. An analysis of the parliamentary discussion concerning the 1997 restraining order legislation illustrates the continuing dominance of the gender-neutral family violence discourse [21]. It was especially the male members of the parliament, who challenged the feminist constructions of DV. For these members, DV was not caused by the patriarchal structures of the society, but signaled the existence of gender-neutral and individual pathologies or sickness. The norm of gender-neutrality characterized the debate, and there were only a few female members of parliament, who, relying upon transnational norms, articulated gendered constructions of DV. In addition, according to the politicians and feminist activists who participated in the policy changes throughout the 1990s, getting the issues of violence against women and feminist equality perspectives onto the political agenda has required a lot of effort, due to the persistent tendency to favor gender-neutrality and the outright rejection of feminist perspectives [24]. An analysis of the Program for the Prevention of Violence Against Women, in turn, reveals that while the program sought to address the issue of DV in gendered terms, it reflected the ongoing adherence to, and contradictions surrounding, the concept of gender-neutrality [3].

What can be concluded from the development of the Finnish DV policies thus far is that Finland lagged behind the other Nordic countries, and many other Western countries, in recognizing DV as an integral part of gender inequality, and that Finnish DV policies and discourses reflected the late arrival of the transnational norms on DV [21]. It was only in the mid-1990s, after intensified transnational pressure, most importantly from the EU, that the Finnish authorities began to properly address the problem. Yet, despite the positive institutional developments, the status of the idea of combatting DV in gendered terms was not very high in 1990s Finland [21]. In this situation, support and pressure from the transnational level would continue to have an important role to play in furthering the progress of Finnish DV policies.

\subsection{The Progress in the 2000 s and 2010s}

Policies addressing violence against women expanded dramatically across the globe during the late 1990s and the first decade of the 2000s [35]. When Finland entered the first decade of the new millennium, some legal changes were made that questioned the earlier emphasis on protecting family unity and the privacy of home at the expense of women's rights [22]. As a combined effect of the transnational pressure and increased domestic activity deriving from the late 1990s, minor assaults in a private place became a mandatory public prosecutorial case in 2004, and a law enabling restraining order within the household came into force in 2005. Despite these changes, an element of the emphasis on keeping families together, rather than punishing perpetrators of DV with prison sentences, continued to prevail as the law on minor assaults in a private place was soon after accompanied by a law on mediation that came into force in 2006 [22]. This kind of conflict mediation has been widely used for cases of DV in the 2000s in Finland, despite continued critique from, for example, women's organizations and the CEDAW-committee. While the principles of mediation conceptualize mediation as equal communication and reconciliation between perpetrator and victim, critics points out that these principles fail to take into account the gendered inequalities that are central in DV. 
In 1995-2005, a shift occurred in Finnish law-making policy away from gender-blindness to the establishing of special measures to tackle violence against women [18]. While "gender-blindness" refers to policies that do not recognize gender as a meaningful category, the "special measures" in question mean that violence against women is acknowledged in criminal policy documents but only as a special case within the framework of "actual" or "real" criminality. In fact, Finnish DV-related legislation falls under the general category of violence rather than violence against women, a distinction that has been central to feminist criticism of gender inequality [17]. In contrast, in 1998, Sweden introduced legislation on "gross violations of women's integrity", which reflects the state's commitment to gender equality and women's rights, and the broader societal view that violence against women is one of the most severe manifestations of gender inequality [18,29]. Moreover, Sweden has not only passed advanced legislation, but gone further in integrating law so that it reflects both legal power and state responsibility in respect to both societal attitudes and funding services.

In contrast to Sweden, Finnish DV policies and services have mostly continued to work within the conceptual tradition of gender-neutrality [3]. An example of the ongoing adherence to gender-neutrality is the fact that no women's centers or network of women-only-shelters exist in Finland, and that most shelters continue to operate under the premise of "family violence". Although the input of civil society actors has been important in the establishment of the Finnish shelters, these actors have mostly been non-feminist actors, and the shelter network has been critiqued by some feminists as being "an embodiment of the family dynamics model" ([21], p. 104). Some researchers have noted a shift from family discourse towards feminist discourse during the 1990s (e.g., [36]). However, an international comparison of crisis centres in Finland, Sweden, Norway and North West Russia (the so-called Barents Region) during the present millennium shows that Finnish crisis centres continued to differ greatly from those of the other countries regarding gender inequality [37]. Unlike the other Nordic and some of the Russian crisis centres, the Finnish ones clearly distanced themselves from feminism, and they also showed the strongest commitment to family welfare.

However, signs can be seen of a discursive shift in DV policy. An analysis of two policy documents initiated by the Finnish government and produced by the Ministry for Social Affairs and Health between 2008 and 2011 shows that the earlier document is almost entirely dominated by gender-neutral discourse, while in the more recent document this discourse is less dominant, having to some extent been replaced by a discourse around the victimhood of women [23]. The earlier document, "Recognize, Protect and Act", portrays DV as a phenomenon which affects men and women equally, and contains no suggestion that any gendered processes or structural inequalities are at work within it. Perhaps more influenced by transnational DV discourses, the later document, "Action Plan to Reduce Violence against Women", underlines women's victimhood. Despite this, a gender analysis of why this gendered asymmetry persists is lacking. Although not all governmental policies fit the description of gender-neutral constructions of DV, a significant gendered discourse about victimization, but not about perpetration, is still evident in this particular document.

In this way, men are invisible even in the more progressive policy documents, leaving the focus on women and their responsibility for ending DV. This is also evident on the level of national policies and services, as there seems to be a persistent tendency to place the onus on the female victim and focus on women's agency in stopping the vicious cycle of DV rather than on the acts of male abusers $[3,19,38]$. In recent decades, however, voluntary rehabilitation programs for violent offenders, offered by private therapists or associations, have emerged in Finland. In the absence of any research on topic, it is plausible that pressure from transnational actors have been important in these most recent policy developments as well. For example, the Council of the EU has urged member states to ensure that the role of men is taken into account in strategies, action plans and other measures aimed at reducing violence against women.

The latest progression in the Finnish DV policies took place in 2015, when Finland finally ratified the Council of Europe Convention on preventing and mitigating violence against women and DV (the so called Istanbul Convention) which was opened for signature in 2011. The Istanbul 
Convention is the first European legally-binding instrument that seeks to create a comprehensive legal framework and approach for combatting violence against women. This development raises the profile of DV policies at the European level and, accordingly, among those Council member states that have ratified the convention. Due particularly to Finland's ratification of the Istanbul Convention, some legal amendments have been made in Finland [18]. For example, as result of change in the law governing prosecution for minor assault in 2011, all domestic assaults are now subject to public prosecution. Currently, Finland is implementing many measures to mitigate violence against women, such as the National Action Plan to Reduce Violence against Women, and is creating government-sponsored shelters.

\section{Policy Development in Terms of Gender Equality}

In order to give a comprehensive overview of Finnish policy development as it relates to gender equality, I draw on the conceptualizations used by Andrea Krizsan and Raluca Maria Popa [5] in their research on DV policies in the Central and Eastern European countries. According to Krizsan and Popa, the relationship between DV policies and gender equality varies within the approach taken. Some approaches explicitly link DV to gender equality, others resonate with the objective of gender equality but remain implicit about its relevance to addressing DV, and yet others contest the premises of gender equality thinking in relation to DV. The continuum of approaches ranges from degendered (rights of individuals subjected to DV) to gendered (structural gender equality). Variation along the continuum from degendered to gendered policy approaches is characterized by the extent to which genderedness on DV is spelled out by the policy, and differences in defining who or which groups of people are affected from DV.

At the degendered end of the continuum is the rights of individuals approach, which refers to a generic category of "victim" and sees DV as the violation of individual human rights, and thus neglects the role of gender inequality as the main social mechanism (re)producing DV. The initial agenda setting in Finland in the 1980s represents this kind of individualizing approach with its emphasis on DV as a private, alcohol- or mental health-related individual problem or the result of unhealthy family dynamics. However, in the 1990s and 2000s, when Finland placed the issue of DV within the context of gender equality by referencing important transnational documents such as the CEDAW, Finnish DV policies moved towards the implicit gender equality approach. Despite doing this, the approach remained mostly gender-neutral and continued to discuss "victims" mainly in general terms, without explicitly referring to DV as a social problem affecting women as a group.

In the 2010s, Finnish policies moved more clearly towards the women-centered approach, which specifies the heightened prevalence of DV against women statistically. However, this approach does not connect with social structural explanations for violence against women either. Even Finland's current policies see DV mainly as a problem that affects individual victims-many of whom just happen to be women. Despite the progress in Finnish DV policies from the 1980s to present day, it seems reasonable to argue that Finnish policies have not yet reached the gendered end of the continuum, namely the structural gender equality approach. (For a timeline showing Finnish policy progress, see Table 1.) This approach understands DV as rooted in gender inequality, thus proposing the transformation of gender inequalities and challenging gender stereotypes as the main means to eliminate DV. The approach is best represented by transnational documents such as the CEDAW and the 1993 Vienna Declaration [5], and it is at the core of a discourse that has been referred to as "feminist" in this article.

Table 1. Timeline of Finnish policy progress in gender equality approaches.

\begin{tabular}{lllll}
\hline $\begin{array}{l}\text { Main Policy } \\
\text { Approaches }\end{array}$ & $\begin{array}{l}\text { Rights of } \\
\text { Individuals }\end{array}$ & $\begin{array}{l}\text { Implicit Gender } \\
\text { Equality }\end{array}$ & Women-Centered & $\begin{array}{l}\text { Structural } \\
\text { Gender Equality }\end{array}$ \\
\hline Finnish policy progress & 1980s & 1990s-2000s & 2010s & - \\
\hline Discourses & Family discourse & $\begin{array}{l}\text { Women-friendly } \\
\text { welfare state discourse }\end{array}$ & $\begin{array}{l}\text { Discourse of women's } \\
\text { victimhood }\end{array}$ & - \\
\hline
\end{tabular}


Based on the exploration of the dynamics of stability and change in the development of Finnish DV policies, it seems that the hegemony of gender-neutralizing discourses has contributed to the continued absence of explicitly gendered constructions of DV, despite increasing recognition of the phenomenon as a form of violence against women (see also [23]). While accepting that women are more likely than men to experience DV, there is a persistent tendency to see DV in gender-neutral terms that do not discriminate between men and women. The violence perpetraded by men and its underlying causes are not addressed and it remains concealed, ignored and unproblematized through the use of gender-neutral language. This failure to acknowledge men's responsibility for DV as a problem is part of the broader absence of a gendered analysis of the phenomenon in the context of policymaking. Whilst the female victims of DV are frequently gendered, and DV's relationship with gender inequality is mentioned, the location of DV within asymmetrical gendered power relations is left largely unexamined.

Consequently, the transformative gender equality content of the transnational gender equality discourses of DV has been modified or has even shrunk as it has been translated and adapted to the national level in Finland. One reason for this is a persistent reluctance to adopt the approach of structural gender equality in Finnish policies. In their analysis of the translation of transnational norms on DV into domestic policy in Central and Eastern European countries, Krizsan and Popa [5] demonstrate the prevalence of several ways of contesting the gender equality content of those norms. Such contestation does not openly reject gender equality, but challenges some of its key tenets or keeps silent about them, with the result that DV policies are constructed in degendered terms. In Finland, too, there seems to be ongoing contestation over gendered and degendered problematizations. The family and child protection-centered, and externalizing approaches appear in particular to play a major role in the contestation of gendered approaches.

As shown earlier, all of these approaches have traditionally been influential in Finnish DV discourses. Externalizing approaches argue that DV is a social problem typical of certain marginalized or deviant subgroups (e.g., alcohol abusers). The family protection approaches characteristics of Finnish DV policies, in turn, see families as the main victims of DV and believe that the unity of family needs to be protected, and thus propose family support or conflict mediation as the primary solutions to the problem. Instead of recognizing the power differentials in DV, there seems to be a somewhat persistent tendency to see DV as a conflict situation between two equal partners or as an alcohol- or mental problem-related issue that has nothing to do with gendered inequality. The child protection approach has several similarities with the family approach, but it differs from family approach arguing that the real victims of DV are children, and that even if women are to be protected from violence this is because of their role as mothers. Yet the child protection approach is often intertwined with the more feminist approaches, and thus advantageous for both children and women, when it is accompanied with efforts to promote both the protection of children who witness DV against women and the protection of abused women [31].

\section{International Comparison of Policy Development}

In an attempt to locate the development of Finnish DV policies at the intersections of space and time, I compare the Finnish timeline with that of other countries. Internationally, significant differences exist between countries in policy timing and progression. In a classification mapping 10 European countries according to when, over the last 40 years, government action against DV has been furthered, Finland is described as "a special case" ([39], p. 610). Originally, Finland was classified as a newcomer in this issue as government action only began to be taken after the mid-1990s. However, when the researchers compared the overall situation in Finland to that in other West European countries, they ended up to classifying Finland in an intermediate position owing to its longer history of women's participation in political life, higher levels of education and access to welfare provisions. (For the classification, see Table 2). 
Table 2. Classification based on time of government action against DV.

\begin{tabular}{ccc}
\hline $\begin{array}{c}\text { Early Bird Countries } \\
\text { (Mid-1970s-Early 1980s) }\end{array}$ & $\begin{array}{c}\text { Intermediate Countries } \\
\text { (Late 1980s-Early 1990s) }\end{array}$ & $\begin{array}{c}\text { Newcomer Countries } \\
\text { (Mid-1990s) }\end{array}$ \\
\hline Holland, Sweden, the UK & Finland, France, Germany, Spain & Italy, Portugal, Slovenia \\
\hline
\end{tabular}

In spite of Finland's privileged position as a welfare state, the more profound comparison between the newcomer countries, intermediate countries, and early bird countries shows that evolution in DV policies does not always follow welfare regimes [40]. In comparison of different welfare regimes [41] and gender regimes [42], the UK emerges as one of the least impressive welfare systems in Europe. Despite this, it is an early bird in DV policy progress compared to the other European countries [40]; in fact, the UK was one of the first countries in the world to take action against DV [30]. Compared to the UK timeline on DV policy development, Finland is clearly a latecomer. This shows that strong welfare state development and gender policy may coexist with gender inequalities and relative gender invisibility [3].

Moreover, Finland's position as a Nordic-style welfare state is no guarantee that it would be progressive in developing a gendered DV policy agenda. Although the Nordic states as a whole hold almost symbolic value as models of progressive social politics in gender equality issues, they are not homogeneous when it comes to DV policies [43]. Sweden is exceptional among this group in explicitly focusing on the link between gender inequalities and DV first, and also earlier than in most of the rest of the world. It represents the success of state feminism in managing to integrate long-standing demands for women-friendly policies facilitating women's access to working life and political participation with radical feminist demands for combatting violence against women [44]. Sweden has continued to maintain its unique position among Nordic states, even though the implementation of policy measures is, in fact, less impressive in Sweden than it may look at the first glance, and, in some respects, the situation has recently been going backwards regarding DV policies and gender equality [45]. Finland, however, differs clearly from all the other Nordic countries on the issue of gender equality with respect to both the the initial agenda setting in the 1980s and the subsequent development of DV policies [31]. For example, by its continued adherence to gender neutrality and open rejection of feminist orientations, Finnish professional work in the field of DV has been shown to be actually closer to the Russian model than the Nordic one (see $[19,37])$.

Despite various socio-cultural, political and other contextual differences, Finland's similarity with Russia and other Eastern and Central European postcommunist countries is evident in their shared tendency to bypass the gendered inequalities linked to DV. Typical of both Finnish and, for example, Russian, Polish, Romanian and Hungarian DV policy development has been a tendency to contest the gender equality content of transnational norms by adherence to family-centered and alcohol- or mental health-related approaches [5,19]. Counter to the other established EU member states, Finland also resembles the Eastern European candidate states in 2000 in its DV policy adaptation mechanisms. In a classification [11] based on the differences in the internal and external pressures toward policy reforms between the EU member states and EU candidate states, Finland was the only EU member state in the group in which violence against women is primarily an internationally rather than domestically driven issue or one that is a progressive combination of both international and domestic pressures.

Finland bears similarities with, for instance, Latvia, Lithuania and Estonia not only in that they have witnessed very little grassroots mobilization against DV, but also that their governments have been initially reluctant to respond to international pressure. Although government policies and domestic mobilization against DV do not directly reflect public opinions, it is interesting to observe the similarities between the above-mentioned Eastern European countries and Finland in this respect. According to a Eurobarometer survey [46], only $66 \%$ of the Latvian population think that violence against women is unacceptable and should always be punishable by law, followed by $67 \%$ in Finland and $68 \%$ in Romania. These are substantially lower figures than those of the more established EU 
member states. In addition, in Finland, far more people (32\%) than across the EU as a whole (12\%) see violence against women as unacceptable but as not always requiring punishment; the corresponding proportion in Latvia is $29 \%$.

Based on the comparison of Finnish DV policies with those of other European countries, it is tempting to state that the Finnish policies represent a grey area between East and West, resembling both Eastern and Western DV policy development. However, the notion of the West as progressive and East as regressive in relation to gendered DV policies is a stereotype based on an over-simplified dualism. Contrary to this stereotype, many Eastern and Central European postcommunist countries joined the process of transnational mobilization on DV at same time as the most of the Western European countries, namely in the mid-1990s, resulting in significant changes to the policy framework in the 2000s [5] in the countries with longer democratic traditions, while the reform in these postcommunist countries came about due to the persistent efforts of both the domestic feminist movement and transnational pressure.

Thus, research findings challenge the stereotype that the Eastern European women's movement was weak and antifeminist, or has had no impact on DV policy in the post-socialist countries $[28,47]$. For example, in Croatia and Slovenia, the feminist movement has played a decisive role in the development of DV policies by putting the issue on the public and political agenda, organizing the first services for female victims, and lobbying for the adaption of transnational norms in local policies [28]. Even Russia, which, due to its gender neotraditionalism, lags behind the other postcommunist states in its DV policies, saw a period of collaboration, from the 1990s to early 2000s, between Russian women's activists and Western feminists. This transnational collaboration funded women's crisis centers, offered them feminist working models and promoted the goal of attitude change in gender equality [47]. Compared to the relatively modest and moderate role of the feminist movement in the Finnish DV policies, some Eastern European countries appear to have been more progressive than Finland.

In addition to the dualism between the "advanced" West and "backward" East, one could challenge the corresponding dualism between North and South. A world-wide study of DV policies over last four decades [30] shows that in the 1990s plenty of countries around the world, including many of those in Latin America and South Asia, began to take action to tackle violence against women. In fact, during this period, the scores of some Latin American countries are higher than those of many European countries, demonstrating that national wealth or lengthy experience of democratic governance does not explain state action on DV. A European comparison [40], in turn, shows that Sweden and Spain are in the vanguards on the issue of violence against women and are the only European countries with DV legislation based on the structural gender equality approach. Sweden represents a Northern European social democratic welfare regime, while Spain represents a Southern conservative model [41]. Welfare patterns, since they are fundamentally gender-neutral, do not reflect or explain what has occurred in individual states' DV policies [40].

The particular ways in which gender equality gets stretched, shrunk, bent or opposed in different countries is dependent on their different political histories and cultural contexts [5]. It seems that the state is a powerful instrument in the development of DV policies based on gender equality, but only on condition that it acts under pressure from or in combination with local activists and transnational bodies $[30,39]$. The existence of strong feminist movements and concerted activism within and across national borders seem to be the most important and consistent factor driving policy change. The results of the above-mentioned world-wide study on DV policies [30] indicate that the effects of autonomous organizing are more important in influencing progressive policy change than the presence of women legislators, the impact of political parties or national wealth. Local feminist activism is not only a helpful, but also a necessary factor in the process of bringing home the value of transnational norms and driving progressive policy change at the national level. This explains, at least in part, why progress in Finnish DV policies has not been as advanced as one might expect from a "women-friendly" welfare state. 


\section{Conclusions}

The main lesson from the research on the development of Finnish DV policies over the last five decades is that even the best of welfare states, enjoying globally high gender equality rankings, may have deficits in certain areas of gender equality. In fact, it is possible that the idealist notion of Finland as a pioneer in the field of gender equality and the belief that gender equality has already been achieved have paradoxically made it difficult to address the remaining gender inequalities, such as men's violence against women [21]. In the end, it was continuous transnational pressure towards better recognition of DV as a gender equality issue that succeeded in challenging this Finnish illusion and allowed for the adoption of new discourses on DV. The main pathway for these transnational influences was through various international treaties and declarations that, simultaneously, created the foundation on which the various national actors could work [11,24].

While it is often assumed that only "non-western" or developing countries benefit from transnational influence in advancing gender equality, the case of Finland shows that a country that is thought to be a pioneer in gender equality can also benefit from transnational discourses [21]. However, these discourses came later and were adopted in a more watered-down fashion in Finland than in many other Western countries. From the mid-1990s to the 2010s, substantial gains have been made in addressing violence against women, but they have taken place within the framework of women-friendly welfare policies rather than within a feminist framework. To keep DV on the national agenda, the local feminist activists moderated the originally feminist perspectives to make them more palatable to mainstream policy actors, and focused their demands on service provision and legal reforms, thus contributing to constructing DV as a practical problem of appropriate social policy solutions and legal responses rather than a problem of structural gender inequality. In addition, the Finnish equality policies have been mainly targeted at working life, and women's victimhood has been more easily recognized and their bodily rights have been better protected in the public sphere (e.g., sexual harassment in the workplace) than in the private sphere.

Advancements in Finnish DV policies have often been hampered by a reluctance to adopt the openly feminist approaches of structural gender equality in the private realm of social life. While the feminist discourse seeks to transform the root causes of DV, the women-friendly welfare discourse narrows its focus to one of taking care of the consequences of DV, for instance by promoting service provisions. While these measures are necessary and useful, they do not adequately address the gender inequalities involved in DV. The unintended result of the coupling of social policy and DV is that by emphasizing social policy solutions rather than criticizing structural gender inequalities, the feminist content of such policy initiatives has been eroded (see also [48]). While feminist and women-friendly welfare discourses may coexist, their basic premises and policy goals differ from each other, especially when it comes to the issue of societal transformation.

However, the welfare state discourse or "state-feminism" as such cannot to be blamed for the moderation of feminist goals, as the case of Sweden shows. The combined effects of a strongly mobilized feminism and favorable political opportunity structures enabled Swedish feminists to use the state as an arena for political activism both for adopting women-friendly policies and for advancing gender equality thinking in relation to DV [44]. In Sweden, feminism has much more positive connotations than it has in Finland as shown, for example, in the fact that many Swedish political parties call themselves feminist. This highlights the significance of the specific local context in adopting transnational frameworks. As a result of their different historical and political trajectories, each locality approaches gender equality differently, which, in turn, influences how transnational feminist discourses are locally appropriated or opposed. The Finnish tendency towards gender-neutrality and rejection of the feminist critique of male dominance may result from Finland's political and societal history of collective and consensus-oriented approaches, traceable to its agrarian values, national movement for independence, the Cold War and the building of a welfare state.

Based on the exploration of the Finnish DV policies over the last five decades, it seems that the progress of DV policies in terms of gender equality has come about primarily through transnational 
pressure. Initially, the transnational influences mediated by feminist activists were opposed at the national level. More forceful transnational pressure was required to enable the breakthrough in Finnish policies in the mid-1990s. While the transnational feminist movement had not any direct effect on this breakthrough, it was the movement's indirect effect through the international treaties and agreements that finally compelled Finland to address the issue. However, even then, the premises of gender equality thinking in relation to DV were contested, and the transformative meanings underpinning the feminist discourses were modified into a more gender-neutral women-friendly welfare discourse. It can therefore be concluded that the interaction between the transnational and national has been a complex process of negotiation, appropriation and contestation over gendered and degendered constructions of DV. This negotiation is an ongoing process, and will continue to influence how Finnish DV policies develop in the future.

Conflicts of Interest: The author declares no conflict of interest.

\section{References}

1. World Economic Forum. “Global Gender Gap Report. Insight Report 2014." Available online: http://www3. weforum.org/docs/GGGR14/GGGR_CompleteReport_2014.pdf (accessed on 28 October 2015).

2. European Union Agency for Fundamental Rights (FRA). “Violence against Women EU-Wide Survey. Main Results Report, 2014." Available online: http:/ / fra.europa.eu/sites/default/files/fra-2014-vaw-surveymain-results-apr14_en.pdf (accessed on 28 October 2015).

3. Hearn, Jeff, and Linda McKie. "Gendered and social hierarchies in problem representation and policy processes: 'Domestic violence' in Finland and Scotland." Violence against Women 16 (2010): 136-58. [CrossRef] [PubMed]

4. Nousiainen, Kevät, Anne Maria Holli, Johanna Kantola, Minna Saari, and Linda Hart. "Theorizing Gender Equality: Perspectives on Power and Legitimacy." Social Politics: International Studies in Gender, State and Society 20 (2013): 41-64. [CrossRef]

5. Krizsan, Andrea, and Raluca Popa. "Frames in contestation: Gendering domestic violence policies in five Central and Eastern European Countries." Violence against Women 20 (2014): 758-82. [CrossRef] [PubMed]

6. Bacchi, Carol. Analysing Policy: What's the Problem Represented to Be? Frenchs Fores: Pearson, 2009.

7. Hearn, Jeff. “Tracking 'the transnational': Studying transnational organizations and managements, and the management of cohesion." Culture and Organization 10 (2004): 273-90. [CrossRef]

8. Hester, Marianne. "Transnational influences on domestic violence policy and action-Exploring developments in China and England." Social Policy \& Society 4 (2005): 447-56. [CrossRef]

9. Merry, Sally E. Human Rights and Gender Violence: Translating International Law into Local Justice. Chicago: University of Chicago Press, 2006.

10. Htun, Mala, and Laurel S. Weldon. "The civic origins of progressive policy change: Combating violence against women in global perspective, 1975-2005." American Political Science Review 103 (2012): 548-69. [CrossRef]

11. Montoya, Celeste. From Global to Grassroots: The European Union, Transnational Advocacy, and Combating Violence against Women. New York: New York University Press, 2013.

12. Zwingel, Susanne. "How do norms travel? Theorizing international women's rights in transnational perspective." International Studies Quarterly 56 (2012): 115-29. [CrossRef]

13. Zhang, Lu. "Domestic violence network in China: Translating the transnational concept of violence against women into local action." Women's Studies International Forum 32 (2009): 227-39. [CrossRef]

14. Davis, Kathy. "Feminist Body/Politics as World Traveler: Translating Our Bodies, Ourselves." European Journal of Women's Studies 9 (2002): 223-47. [CrossRef]

15. Lombardo, Emanuela, Petra Meier, and Mieke Verloo. The Discoursive Politics of Gender Equality: Stretching, Bending, and Policy-Making. London: Routledge, 2009.

16. Kantola, Johanna. "Doing feminist discourse analysis: Domestic violence in the women-friendly welfare state of Finland." European Political Science 4 (2004): 85-96. [CrossRef]

17. Clarke, Kris. "The paradoxical approach to intimate partner violence in Finland." International Perspectives on Victimology 6 (2011): 9-19. 
18. Niemi, Johanna. Gender and Criminal Law Policy. Turku: University of Turku, 2015. Available online: https: //www.utu.fi/en/units/law/faculty/people/Documents/gender_and_criminal_law_policy.pdf (accessed on 28 June 2016).

19. Virkki, Tuija, and Maija Jäppinen. “Gendering Responsibility. Finnish and Russian Helping Professionals' Views on Responsible Agency in the Context of Intimate Partner Violence." In Interpersonal Violence. Differences and Connections. Edited by Marita Husso, Tuija Virkki, Marianne Notko, Helena Hirvonen and Jari Eilola. London: Routledge, 2017, pp. 107-21.

20. Bergman, Solveig. "Women in New Social Movements." In Equal Democracies? Gender and Politics in the Nordic Countries. Edited by Christina Berqvist, Anette Borchorst, Ann-Dorte Christensen, Nina Raaum and Audur Styrkadottir. Oslo: Scandinavian University Press, 1999, pp. 97-117.

21. Kantola, Johanna. Feminists Theorize the State. Basingstoke: Palgrave Macmillan, 2006.

22. Kotanen, Riikka. Näkymättömästä Näkökulmaksi. Parisuhdeväkivallan Uhrit ja Oikeudellisen Sääntelyn Muutos Suomessa [From Invisible to Visible. Victims of Intimate Partner Violence and Legal Changes in Finland]. Helsinki: Helsingin yliopisto, 2013.

23. Burrell, Stephen. The Invisibility of Men's Practices. A Discourse Analysis of Gender in Domestic Violence Policy. Tampere: University of Tampere, 2014.

24. Pehkonen, Pirjo. Naisen Puolesta, Ei Miestä Vastaan. Suomalainen Naisliike Väkivaltaa Vastustamassa [Working on Behalf of Women, Not against Men. The Finnish Feminist Movement against Domestic Violence]. Joensuu: Joensuun yliopisto, 2003.

25. Zwingler, Susanne. How do International Women's Rights Norms Become Affective in Domestic Contexts? An Analysis of the Convention on the Elimination of all Forms of Discrimination against Women (CEDAW). Bochum: Bochum University, 2005.

26. World Economic Forum. "Human Capital Report 2015." Available online: http://reports.weforum.org/ human-capital-report-2015/ (accessed on 28 October 2015).

27. Arnold, Gretchen, and Jami Ake. "Reframing the narrative of the battered women's movement." Violence against Women 19 (2013): 557-78. [CrossRef] [PubMed]

28. Spehar, Andrea. "Women's movements as agents of change: The politics of policymaking and the reform of domestic violence laws in Croatia and Slovenia 1991-2004." Journal of Women, Politics E Policy 33 (2012): 205-38. [CrossRef]

29. Peter, Tracey. "Domestic violence in the United States and Sweden: A welfare state typology Comparison within a power resources framework." Women's Studies International Forum 29 (2006): 96-107. [CrossRef]

30. Weldon, Laurel S., and Mala Htun. "Feminist mobilisation and progressive policy change: Why governments take action to combat violence against women." Gender $\mathcal{E}$ Development 21 (2013): 231-47. [CrossRef]

31. Eriksson, Maria. “Justice or welfare? Nordic women's shelters and children's rights organizations on children exposed to violence." Journal of Scandinavian Studies in Criminology and Crime Prevention 11 (2010): 66-85. [CrossRef]

32. Ronkainen, Suvi. “Gendered violence and genderless gender." Kvinder, Køn \& Forskning 10 (2001): 45-57.

33. Julkunen, Raija. Sukupuolen Järjestykset ja Tasa-Arvon Paradoksit [Gendered Orders and Paradoxes of Gender Equality]. Tampere: Vastapaino, 2010.

34. Krizsan, Andrea, and Raluca Popa. "Europeanization in making policies against domestic violence in Central and Eastern Europe." Social Politics 17 (2010): 379-406. [CrossRef] [PubMed]

35. Pierotti, Rachel S. "Increasing rejection of domestic violence: Evidence of global cultural diffusion." American Sociological Review 78 (2013): 240-65. [CrossRef]

36. Nyqvist, Leo. Väkivaltainen Parisuhde, Asiakkuus ja Muutos [Intimate Partner Violence, Clienthood and Change]. Helsinki: Ensi- ja turvakotien liitto, 2001.

37. Liapounova, Olga, and Irina Drachova. "Crisis centres for women in North West Russia: Ideology, management and practice." In Crisis Centres and Violence against Women. Dialogue in the Barent Region. Edited by Aino Saarinen and Elaine Carey-Belanger. Oulu: Oulu University Press, 2004, pp. 39-68.

38. Virkki, Tuija. "Social and health care professionals' views on responsible agency in the process of ending intimate partner violence." Violence against Women 21 (2015): 712-33. [CrossRef] [PubMed]

39. Corradi, Consuelo, and Heidi Stöckl. "Intimate partner homicide in 10 European countries: Statistical data and policy development in a cross-national perspective." European Journal of Criminology 11 (2014): 601-18. [CrossRef] 
40. Corradi, Consuelo. "Recasting Welfare Regimes for Gender Equality." Paper presented at the European Sociological Association Conference, Prague, Czech Republic, 25-28 August 2015.

41. Espingen-Andersen, Gösta. The Three Worlds of Welfare Capitalism. Cambridge: Polity Press, 1990.

42. Sainsbury, Diane. Gender, Equality and Welfare States. Cambridge: Cambridge University Press, 1999.

43. Balkmar, Dag, LeeAnn Iovanni, and Keith Pringle. "A reconsideration of two Welfare Paradises. Research and policy responses to men's Violence in Denmark and Sweden." Men and Masculinities 12 (2009): 155-74. [CrossRef]

44. Borchorst, Anette, and Birte Siim. "Women-friendly policies and state feminism. Theorizing Scandinavian gender equality." Feminist Theory 9 (2008): 207-24. [CrossRef]

45. Eriksson, Maria. “Mäns Våld mot Kvinnor och Kroppslig Integritet [Men's Violence against Women and Bodily Integrity]." 2014. Available online: http:/ / www.sou.gov.se/wp-content/uploads/2015/03/U-201406-Eriksson-1508291.pdf (accessed on 10 February 2017).

46. European Commission. "Domestic Violence against Women Report. Special Eurobarometer 344, 2010." Available online: http://ec.europa.eu/public_opinion/archives/ebs/ebs_344_en.pdf (accessed on 28 October 2015).

47. Hemment, Julie. "Global civil society and the local costs of belonging: Defining violence against women in Russia." Signs 29 (2004): 815-40. [CrossRef]

48. Abraham, Margaret, and Evangelia Tastsoglou. "Addressing domestic violence in Canada and the United States: The uneasy co-habitation of women and the state." Current Sociology 64 (2016): 568-85. [CrossRef]

(C) 2017 by the author. Licensee MDPI, Basel, Switzerland. This article is an open access article distributed under the terms and conditions of the Creative Commons Attribution (CC BY) license (http:/ / creativecommons.org/licenses/by/4.0/). 